\title{
BLADES INTERACTION AND NON-STATIONARITY OF FLOW IN VERTICAL-AXIAL WIND TURBINES
}

\author{
Ludmila ROZHKOVA \\ Sumy National Agrarian University \\ Tibor KRENICKY \\ Technical University of Kosice \\ Eduard KUZNETSOV, Volodymyr NAHORNYI \\ Sumy State University
}

\begin{abstract}
:
Until recently, horizontal-axial wind turbines with blades having a wing profile occupied a predominant position in the world wind energy market. But currently, vertical-axial wind units are of increasing interest and this is understandable from the point of view of their important features as: no requirements for the orientation of the wind turbine to the wind, the possibility of placing electrical and other equipment on the ground, no requirements for changes of blade chord installation angle along its length. The article discusses the aerodynamics of the vertical-axis wind turbines: the range of changes of angles of incoming flow attack on the blade, the dynamics of changes in the magnitude of the absolute speed of flow of the blade on a circular trajectory of its movement depending on the turbine rapidity, and also obtained in experiments interaction effect of the blades in the rotor. The experiments were carried out on wind turbines with original blades (basic version), which were designed to eliminate the shortcomings of low-speed rotors Savonius (low coefficient of use of wind energy) and high-speed rotors Darrieus (lack of self-start).
\end{abstract}

Key words: wind turbine, power characteristic, wind potential, filling factor, wind energy utilization

\section{INTRODUCTION}

Currently, wind energy has received a special development in the world practice, which is explained by the availability and free of charge of wind energy, the possibility of installing a wind unit, almost anywhere with sufficient wind potential. Until recently, the global wind power market was dominated by horizontal-axial wind turbines with wing-shaped blades. This is explained by a longer history of use and a fairly high coefficient of use of wind energy. However, at present, vertical-axial wind turbines are of increasing interest and this is quite understandable from the point of view of their following features:

- the absence of requirements for the orientation of the wind turbine to the wind, which increases the energy performance of the wind turbine by eliminating losses when changing the orientation and improves the conditions of operational maintenance;

- the possibility of placing electrical and other equipment on the ground;
- low sensitivity of the turbine to the phenomenon of non-planarity of the wind;

- the absence of a twist of the blade in the span, which simplifies and, as a result, reduces the cost of the blade design. Since, according to [1, 2], the cost of the wind turbine is $40 \%$ of the total cost of the wind unit, the reduction in the cost of the wind turbine even to a small extent gives a significant economic benefit;

- reduced gyroscopic effects.

At the present stage of wind power development, small autonomous wind units have great prospects. It should be noted that the development of small wind units as autonomous ones is largely carried out using vertical-axial wind turbines. This is especially economically advantageous for urban conditions, since the wind direction changes constantly and unpredictably in the presence of swirls between houses. If at the end of the twentieth century vertical-axis wind turbines were produced mainly in Canada, 
Germany, England, now it is also Italy, the United States, Japan, China and other countries.

\section{LITERATURE REVIEW}

Recently, a certain amount of research has been accumulated, as well as experience in the design and operation of vertical-axis wind turbines. Thus, a large amount of information on small vertical wind turbines is given in [3]. In [3, 4], it is noted that the Savonius rotor is in demand, despite the low coefficient of wind energy use. The Darrieus rotor has a fairly high coefficient of wind energy use, but often there is no self-start of this rotor and the problem is solved by using special devices. In [5], the results of studies of the two-tier Savonius rotor are presented. Information on studies of the aerodynamic and energy characteristics of the Savonius and Darrieus rotors is given in [4, $5,6,7,8,9,10,11,12,13]$.

Experimental study of the energy performance of savonius rotor has set the maximum of wind energy utilization coefficient $(0.2)$ and the presence of guaranteed selfstarting rotor [5].

In [6], an analogy is proposed for the non-stationary flow around the blades of the Darrieus wind turbine with the flow around the flapping wing of a bird. This hypothesis, according to the author, suggests that the Darrieus rotor may have values of the wind energy utilization coefficient greater than the Betz-Glauert criteria.

In experimental studies, "the ideal rotor" (without shaft and traverses) is fixed, the limit of wind energy utilization coefficient $0.72[7,8]$. Therefore, the assumption that the wind energy utilization coefficient of vertical-axis wind turbines may exceed similar parameters of horizontal-axis wind turbines may be fair.

Thus, it is logical to conclude that there are great prospects for the development of wind units with vertical-axial wind turbines $[9,10]$.

In addition to the above information, earlier model studies of the rotors of vertical-axial wind turbines in order to assess their performance and select the optimal design are known [14, 15, 16, 17, 18]. Generalized results were obtained and recommendations were developed for specific blade systems in terms of the geometry of the blades (profile thickness, the ratio of the profile chord to the rotor diameter, as well as blade elongation), the optimal value of the rotor fill factor $\sigma$, etc. $[19,20,21]$. Similar studies of the aerodynamic characteristics of vertical-axial wind turbines with straight wing blades, conducted at TsAGI and at the Kharkov Aviation Institute $[13,14]$ were aimed at determining the energy characteristics of specific wind turbines of a vertical-axial wind units.

However, to the influence of the unsteadiness of the aerodynamics of vertical-axial wind turbines was not paid appropriate attention in these works. As for the mutual influence of the blades in the wind turbine, it was indirectly traced when determining the optimal value of the rotor fill factor. Thus, the problem of non-stationary flow around the blades and their mutual influence in the wind turbine is still not fully investigated. However, the answer to these questions is important for the design of verticalaxis wind units [22].
According to [4], the main source of information in the design of vertical-axial wind turbines can only be an experiment, since the theoretical calculation models for them need serious refinement within the framework of the nonlinear theory of the wing [23].

The purpose of the article is to show the process of formation and dynamics of changes in the pulling force along the circular trajectory of the blade in a vertical-axial wind turbine, the dynamics of changes in the angle of attack and the absolute flow velocity [24], which gives a clear idea of the nature and degree of non-stationary aerodynamics of such wind turbines. In addition, the effect of the mutual influence of the blades in a vertical-axial wind turbine of medium speed $(1<\vartheta \leq 3)$ obtained in experimental studies is shown.

It should be noted that the features of the wind turbine aerodynamics of vertical-axial units, in fact, determine the ways to improve the blades used in the wind turbine [25, $26,27,28]$.

\section{METHODS, RESULTS, AND DISCUSSION}

The analysis of the aerodynamics of the blade system of a vertical-axial wind turbine is carried out by computational and experimental methods. Features of the flow lining of a single blade vertical-axis wind unit subject to its motion on a circular path around a vertical axis (Fig. 1).

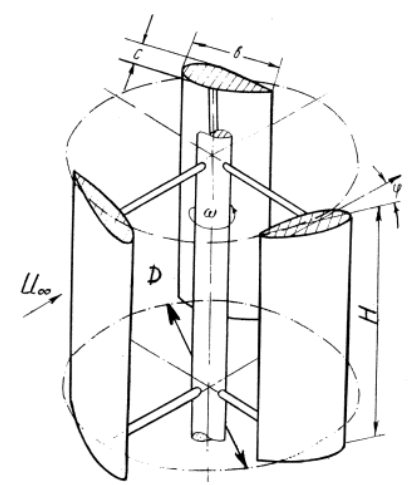

Fig. 1 Diagram of a wind turbine of a vertical-axial wind unit with symmetrical profile blades

With a constant direction of wind flow $\left(U_{\infty}\right)$ the direction and magnitude of the absolute velocity of the flow around the blades will change, thus, will change the magnitude and angle of attack of the incoming flow (Fig. 2).

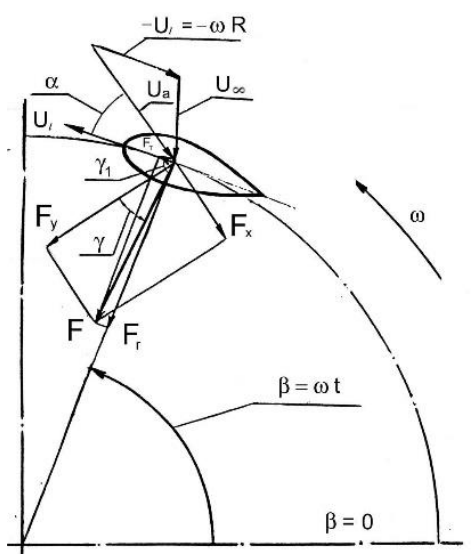

Fig. 2 Flow diagram and the formation of the pulling force on the wing-shaped blades in the vertical-axial unit 
When the blade moves with a speed $U_{1}$ along a circular trajectory, a flow runs into it at a certain angle of attack $\alpha$, the speed of which $U_{a}$ is equal to the vector difference between the wind speed $U_{\infty}$ and the speed of the blade $U_{1}$. The resulting lifting force $F_{y}$ and the resistance force of the blade $F_{x}$ form the total aerodynamic force $F$, the projection of which on the direction of movement of the blade is the pulling force $F_{\mathrm{T}}$. Thus, the pulling force is a function of the wind speed, the circumferential speed of the blade, the angle of attack $\alpha$ : $F_{\mathrm{T}}=f\left(U_{\infty}, U_{\mathrm{l}}, \alpha\right)$. In turn, the angle of attack is a function of the central (azimuthal) angle that determines the position of the blade on a circular trajectory at a given time.

It is clear that the value of $F_{\mathrm{T}}$ the greater the lower the resistance force $F_{\mathrm{x}}$ and the greater the lifting force $F_{\mathrm{y}}$ and the angle $\alpha$. Consequently, an increase $F_{\mathrm{T}}$ can be achieved, on the one hand, by an increase $\alpha$, on the other hand, by a decrease in the resistance force $F_{\mathrm{x}}$ and an increase in the lifting force $F_{\mathrm{y}}$.

However, for the values $\alpha$, as is known, there are limitations due to the aerodynamic properties of the wing profile used, since the effective operation of the wing blade is possible only with a continuous flow mode. For known wing profiles, the critical value does not exceed $20^{\circ}$ and the increase $F_{\mathrm{T}}$ due to the increase $\alpha$ can only be carried out within the nominal range of angles of attack for the applied profile.

Reduction $F_{\mathrm{x}}$ and increase $F_{\mathrm{y}}$ is possible by increasing the aerodynamic quality of the blade profile, which generally characterizes the parameter $K=F_{y} / F_{x}$. At the same time, it should be taken into account that an increase in the aerodynamic quality of the wing blade should increase the speed of the blade $U_{1}$ and shift the power characteristic of the wind unit to the region of higher speed coefficients $\vartheta$. The lifting force at the same value of the wind speed $U_{\infty}$ is directly proportional to the speed of the blade, as can be seen from the speed triangle (Fig. 2). However, the work of the wind unit in the region of higher values of $\vartheta$ means, in turn, a decrease $\alpha$ and, accordingly, the pulling force $F_{\mathrm{T}}$. Thus, the optimal mode of operation of the wind unit rotor with a specific type of blades can be determined experimentally in each specific case.

When considering the non-stationary phenomena that occur during the flow around the blades of vertical-axial wind units, they should be classified from the point of view of the nature of non-stationarity [29].

On the one hand, the blade elements of all types of wind units (including horizontal ones) are exposed to non-stationary effects due to the instability of wind characteristics. Atmospheric currents are characterized by both seasonal and diurnal state variability [1]. In addition, there are other types of fluctuations, such as, for example, created by the turbulence of the incoming flow, etc., the period of which can be from a fraction of a second to several days. The non-stationarity associated with wind instability can be classified as non-stationarity of the first kind. Of course, its impact should be taken into account when choosing the type of wind turbine, in aerodynamic, strength and other calculations of both horizontal-axial and vertical-axial wind turbines, since the behaviour of the blades in a non-stationary flow differs from that in stationary conditions. The calculation of the effect of nonstationary gusts of the incoming flow on the flow around the profile is proposed, for example, in [15].

The nonstationarity of the second kind is due to the peculiarities of the flow around the blade of the vertical-axial wind units when it moves along a circular trajectory. The main characteristics of non-stationarity in this case are cyclic changes in the angle of attack $\alpha$ and the absolute velocity $U_{a}$ of the flow around the blade. Analysis of nonstationary of process will hold under the assumption that the wind speed and the rotational speed of the wind unit rotor are constant, the braking of the flow and mutual influence of the blades are absent, and the angle of the blades $\varphi$ is equal to 0 . Diagrams of the wind turbine and the flow around the blade and the forces acting on it when moving along a circular trajectory are shown in Fig. 1 and Fig. 2. We will consider the process as quasi-stationary, i.e., one in which the influence of the dynamics of changes in the flow characteristics is not taken into account.

Under the accepted conditions, the values of the angle of attack $\alpha$ and the absolute velocity of the flow around the blade $U_{a}$ depend, as already noted, on the position of the blade on the circular trajectory at each considered moment and on the speed coefficient value $\vartheta$. In turn, the position of the blade is determined by the value of the socalled azimuth angle 6 , calculated from a certain conditionally fixed base (in Fig. 2, indicated by zero) and generally equal $\omega t$,

where:

$\omega-$ is the speed of rotation,

$t-$ is the time elapsed from the moment of entering the steady-state operating mode.

In our case, the point of the circular trajectory lying on the diameter perpendicular to the wind direction, in which the blade is oriented towards the flow, is chosen $B=0$.

Using the known mathematical relations, we write down expressions for determining the angle of attack $\alpha$ and the absolute velocity of the flow around the blade $U_{\mathrm{a}}$ :

$$
\alpha= \pm \arcsin \left(U_{\infty} \times \frac{\sin (\beta)}{U_{a}}\right)= \pm \arcsin \left(U_{\infty} \times \frac{\sin (\omega t)}{U_{a}}\right)
$$

A positive value $\alpha$ is taken when the flow flows on the side of the blade external to the rotor shaft and occurs at $0<$ $\omega t<\pi$, then changes the sign to a negative at $\pi<\omega t<2 \pi$ (within the first turn of the blade).

Absolute flow velocity of the blade:

$$
U_{a}^{2}=U_{\infty}^{2}+U_{l}^{2}+2 U_{\infty} U_{k} \cos (\omega t)
$$

Taking into account the fact that $U_{1}=U_{\infty} \cdot \vartheta$, we get:

$$
U_{a}=U_{\infty} \sqrt{1+\theta^{2}+2 \theta \cos (\omega t)} \text {. }
$$

Hence the angle of attack is:

$$
\alpha= \pm \arcsin \left(\sin (\omega t) / \sqrt{1+\theta^{2}+2 \theta \cos (\omega t)}\right)
$$

The values $\alpha$ and $U_{\mathrm{a}}$, are functions of the argument $\omega t$ and are periodically changing over time, and the frequency of repetition depends on the frequency of rotation of the wind unit rotor and, consequently, on the value of the speed coefficient. The oscillations $\alpha$ and $U_{a}$ within the limits $0<\omega t<2 \pi$, i.e. within one turn of the blade, for different values of the speed coefficient $\vartheta$ differ in amplitude, and for $\alpha$ also the position of the maximum (in absolute 
value), as shown in the corresponding graphs in Fig. 3 and Fig. 4.

Fig. 3 shows the dependences $\alpha=f(\omega t)$ for different speed coefficients $\vartheta$ within one turn of the blade.

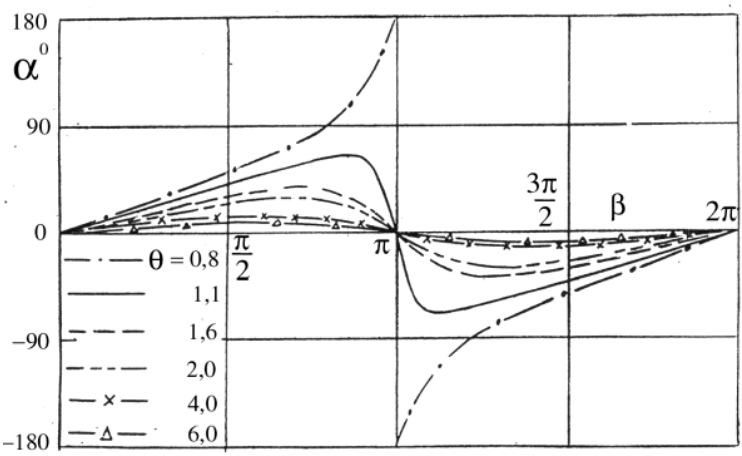

Fig. 3 Dependence $\alpha=f(B)$ at $\vartheta=$ var

In the case of $\vartheta \leq 1$, the function $\alpha=f(\omega t)$ suffers a break at $\omega t=\pi$ and changes the sign to the opposite, and the sign change occurs also at $\vartheta>1$. As you increase $\vartheta$ the maximum achievable (in absolute value) value of the angle of attack decreases. The incoming on the blades of the vertical-axial wind unit flow will be more or less slowed down on the windward part, which will lead to a decrease $\alpha$ in the absolute value on the leeward side of the rotor. It should be noted that with an increase $\vartheta$, there is not only a decrease $\left|\alpha_{\max }\right|$, but also a shift in its position along the azimuth angle from $\pi(1+2 n)$ to $\pi(1 / 2+2 n)$ on the windward side and to $\pi(3 / 2+2 n)$ on the leeward side ( $n$ changes from 0 at the first turn of the blade to $\infty$ ) as is clearly seen in Fig. 3. This shift has a positive effect, since the position of the maximum value of the angle of attack in this case moves to the region of high speed values $U_{\text {a }}$. Since the continuous flow of the wing blades takes place in the range of the angles of attack $\alpha=\left|20^{\circ}\right|$, the effective operation of the vertical-axial wind units with these blades is possible at the values of the speed coefficient $\vartheta \geq 4$.

The dynamics of the change in the value of the absolute velocity $U_{a}$ of the flow around the blade along the circular trajectory of its movement (or, what is the same, along the azimuthal angle $b=\omega t$ ) is shown in Fig. 4 .

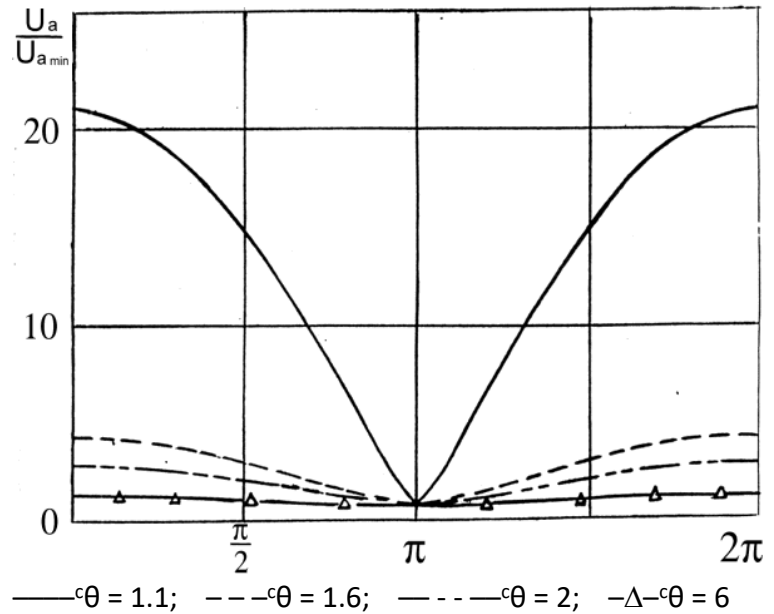

Fig. 4 Dependency $U_{a} / U_{a \min }=f(B)$ for different values of $\vartheta$
The degree of non-stationarity $U_{\mathrm{a}}$ is also determined by the speed coefficient $\vartheta$ and increases with decreasing value, as shown by the dependence $U_{\mathrm{a}} / U_{\mathrm{a} \text { min }}=f(\omega t)$ at different values $\vartheta$. Here $U_{a}$ and $U_{\text {a min }}-$ respectively, the value of the absolute velocity of the flow around the blade in a certain position on a circular trajectory and its minimum value $\left(U_{\mathrm{a} \min }=U_{\infty}-\omega R\right)$, taken at the same time $\vartheta$. In accordance with the system of reference we have adopted, the minimum absolute velocity is observed at $B=\omega t=\pi(1$ $+2 n)$. With different in $\vartheta$ operating modes of the verticalaxial wind unit rotor, the maximum values of the ratio $U_{\mathrm{a}} / U_{\mathrm{a}}$ min can differ significantly from each other. So, for example, the value $U_{\mathrm{a}} / U_{\mathrm{a}}$ min reaches 21 at $\vartheta, \vartheta=1.1$, and at $\vartheta, \vartheta=2$ is only 3 . In other words, the oscillation amplitude $\alpha$ and $U_{\text {a }}$ decreases with increasing $\vartheta$, but it should be borne in mind that the number of oscillation cycles increases simultaneously for the same period of time.

As mentioned above, the dynamics of $\alpha$ and $U_{a}$ along a circular trajectory is analysed for a single blade without taking into account such phenomena as braking and bevelling of the wind flow in the wind turbine. The actual flow pattern of the blade in the wind turbine, therefore, will be different, since the absolute flow rate $U_{\text {a }}$ due to braking on the leeward side of the wind turbine is less than on the windward side. In general, there is a direct dependence of the braking coefficient $k=\left(U_{\infty}-U_{2}\right)$, where $U_{2}-$ is the flow rate behind the wind turbine, on the fill coefficient (shading) $\alpha$ and speed coefficient $\vartheta$, as well as the type of blades. Since the wind speed loss in the wind turbine cannot exceed $2 / 3$ of $U_{\infty}$ [6], the maximum permissible maximum value of the flow braking coefficient behind the wind turbine $k=2 / 3$. The value of the flow bevelling is determined by the same parameters as the wind flow braking and affects the value of the angle of attack and, consequently, the value of the absolute speed. The exact real characteristics of wind turbines can only be obtained experimentally so far. However, the accumulation of experimental data for a certain type of wind units can allow the correction of its characteristics in a wide range of standard sizes by calculation.

The question of the mutual influence of the blades on the characteristics of the vertical-axial wind turbine is also important. The answer to this question was obtained experimentally. Experimental studies of models of the original blades and model rotors of vertical-axial wind units with these blades were carried out in the hydrobasin of the Institute of Hydromechanics of the Academy of Sciences of Ukraine $[16,17]$. The original shape of the blades was proposed to eliminate the disadvantages of low-speed Savonius rotors (low coefficient of wind energy utilization) and high-speed Darrieus rotors (lack of self-starting). The proposed blades were the basic ones for this type of blades. The objectives of the tests were:

1) determination of the coefficients of lifting force $C_{y}$ and resistance force $C_{x}$ of the original blades having an open wing profile ( $\mathrm{KN}$ type) when the angle of attack of the incoming flow changes from 0 to $360^{\circ}$ (the socalled "circular blowing"). 
2) obtaining the power characteristics of a rotor $C_{p}=f(\vartheta)$ with $\mathrm{KN}$ blades when changing its geometric parameters, such as the number of blades and the angle of their installation $\varphi$.

Three variants of the profiles of the $\mathrm{KN}$ blades and rotors with them were studied (Fig. 5), and the author's certificates for the invention were obtained for the rotor and the blade with the $\mathrm{KN}-4$ profile $[18,19]$. In the studies, were obtained the aerodynamic characteristics (the coefficient of lifting force $C_{y}$ and the coefficient of resistance force $C_{x}$ ), models of blades and power characteristics of models of vertical-axial wind units rotors $C_{p}=f(\vartheta)$, where:

$C_{p}$ - the wind energy utilization coefficient is a function of the speed coefficient $\vartheta$.

Since the best experimental power characteristic was the rotor model with $\mathrm{KN}-4$ blades, the power characteristics of the rotor model with $\mathrm{KN}-4$ blades were calculated based on the aerodynamic characteristics of this blade. The results of calculating the power characteristics were compared with the results of the experiment.
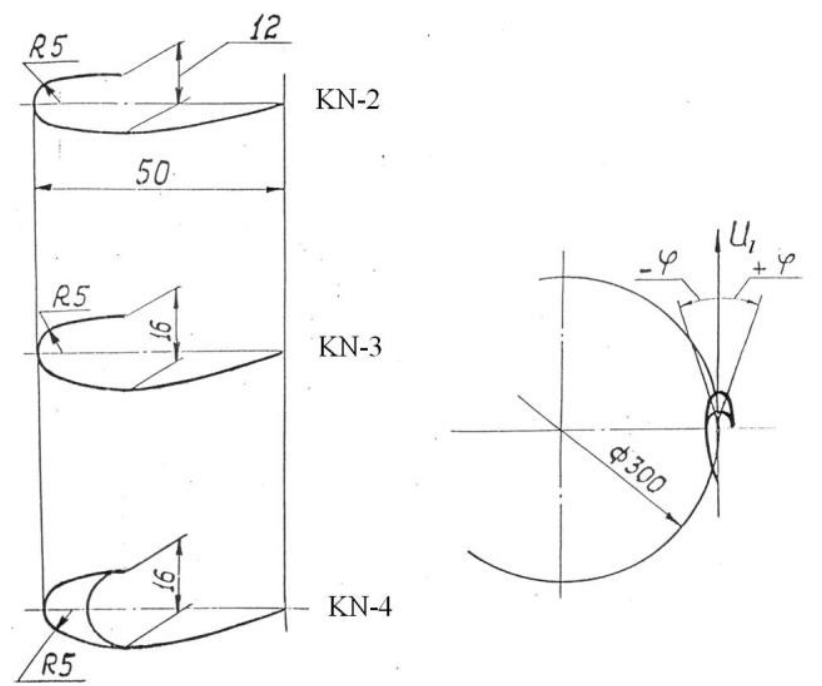

Fig. 5 Profiles and installation diagram of the KN blades in the rotor model

Figure 6 shows the calculated and experimentally obtained power characteristics for the model of a rotor with $\mathrm{KN}-4$ blades with a number of blades $i=3$ and $i=5$.

According to the calculation $C_{p}$ using $C_{y}$ and $C_{x}$ increasing the number of blades in the wind turbine from 3 to 5 (for a rotor with $\mathrm{KN}-4$ blades) significantly increases $C_{\mathrm{p}}$ (almost twice). In the experiment, this effect was not observed, on the contrary, there was a shift in the rotor power characteristic to the region of lower speed and a decrease $C_{p}$. Thus, a comparison of the calculated power characteristics and those obtained in the experiment proves the presence of the effect of mutual influence of the blades in the wind turbine of a vertical-axial wind unit. So, the optimal value of the calculated characteristics of the power $C_{p}=f(\vartheta)$ for rotor with 3 blades shifted in speed coefficient $\vartheta$ somewhat to the right of optimum experimental characteristics of power for rotor with the same number of blades, and greater $C_{p}$.

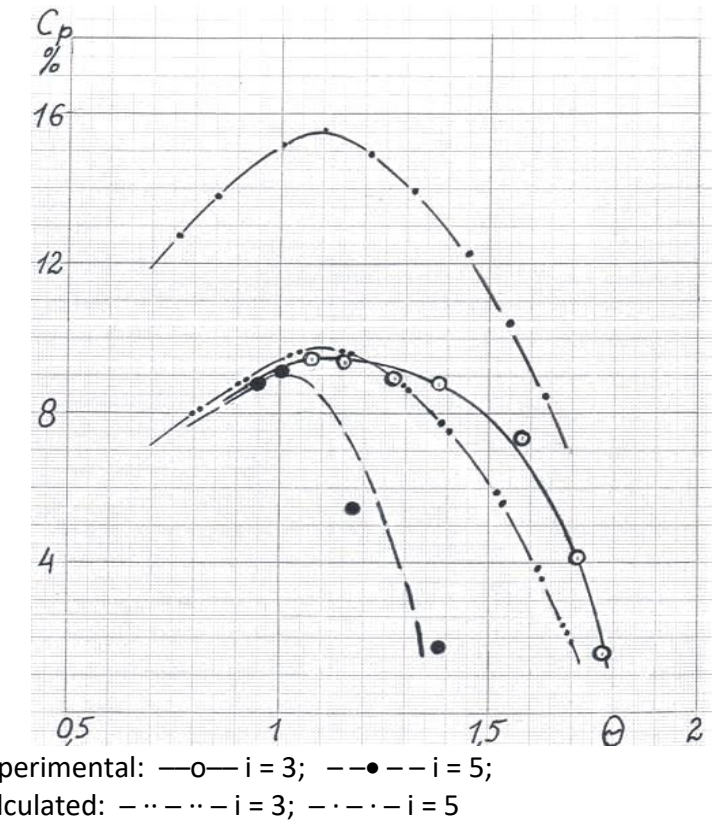

Fig. 6 Power characteristics $C_{p}=f(\vartheta)$ for the $K N-4$ blade rotor model

The diameter of the rotor model and the value of the chord of the blades were unchanged in the experiment. With an increase in the number of blades from 3 to 5 , the filling factor of the wind turbine $\sigma$ increased (from 0.5 to 0.8 ), which caused a greater effect of braking and bevelling the flow. As a result, the optimum of the experimental power characteristic $C_{p}=f(\vartheta)$ moved to the left, to the area of lower speed, and the value $C_{p}$ significantly decreased in comparison with the calculated power characteristic (Fig. 6).

It should be noted that the fill factor is obviously crucial for the amount of braking and bevelling of the incoming flow and, therefore, for the power characteristic of the wind turbine. For rotors with KN blades, the optimal value of the filling factor should be selected from a certain range of values [20] experimentally, since $\sigma$ depends on the chord length, the relative thickness of the blades and their number [30, 31, 32, 33].

So, a comparison of the calculated and experimental results of studies of the power characteristics of models of rotors with $\mathrm{KN}$ blades shows their significant difference, which makes it difficult to accurately calculate the power characteristics of a wind turbine using the aerodynamic characteristics of the blades.

Thus, we should agree with the conclusion [4] that at the present stage, the accuracy of the power characteristics of vertical-axial units can only be guaranteed experimentally, since the calculation methods for them are still incomplete.

\section{CONCLUSIONS}

1. The non-stationarity of the wind turbine aerodynamics of vertical-axial wind units increases with a decrease in the speed coefficient $\vartheta$ of the blade system.

2. The decrease of the coefficient of speed coefficient $\vartheta$ of blade system leads to a decrease in the centrifugal force on the blades and, consequently, to lower 
strength requirements of the suspension of the blades and other components of wind unit.

3. The effect of the mutual influence of the blades in the vertical-axial wind turbine is causes the braking of the wind flow on the windward side of the wind turbine.

4. The degree of wind flow braking obviously depends on the filling factor of the wind turbine.

5. The exact magnitude of the effect of the mutual influence of the blades in a vertical-axial wind turbine can be determined at present only in experimental studies.

6. The ways to improve the blade system of a verticalaxial wind turbine are in the plane of increasing its adaptability, especially in the area of average speed values.

7. The accuracy of the power characteristics of verticalaxial wind units can currently be guaranteed only by experiment.

\section{ACKNOWLEDGMENTS}

This work was supported by the Slovak Ministry of Education within project VEGA No. 1/0823/21 and by the Slovak Research and Development Agency under contract No. APVV-18-0316.

\section{REFERENCES}

[1] D.J. De Renzo. Vetroenergetika [Wind energy]. Moscow, 272 p., 1982.

[2] J.W. Twidell and A.D. Weir. Renewable Energy Resources. London, E. \& F.N. Spon, 392 p., 1986.

[3] V.A. Dzendzerskiy, S. Tarasov and I. Kostyukov. Vetroustanovki maloi moshchnosti [Low power wind turbines]. Kiev, 591 p., 2011. (in Russian)

[4] D.N. Gorelov. Aerodinamika vetrokolyos s vertikalnoi osyu vrashcheniya [Aerodynamics of wind turbine with vertical axis of rotation]. Omsk, 68 p., 2012. (in Russian)

[5] D.N. Gorelov. "Eksperimentalnoe issledovanie energeticheskikh kharakteristik dvukhyarusnogo rotora Savoniusa" [Experimental study of energy characteristics of Savonius twin-tier rotor]". Teplofizika i aeromekhanika, 2005, vol. 12, no. 4, pp. 693-696. (in Russian)

[6] D.N. Gorelov. "Problemy aerodinamiki vetrokolesa Dar'e [Problems of Darrieus wind turbine aerodynamics]". Teplofizika i aeromekhanika, 2005, vol. 10, no. 1, pp. 47-51. (in Russian)

[7] D.N. Gorelov and Yu.N. Kuzmenko. "Eksperimentalnaya otsenka predelnoi moshchnosti vetrokolesa s vertikalnoi osyu vrashcheniya [Experimental estimation of the maximum power of a wind turbine with a vertical axis of rotation]". Teplofizika i aeromekhanika, 2001, vol. 8, no. 2, pp. 329-331. (in Russian)

[8] D.N. Gorelov, V.V. V'yugov and V.P. Krivospitskii. "Eksperimental'noe issledovanie dvukhyarusnogo rotora Dar'e [Experimental study of Darrieus twin-tier rotor]". Teplofizika i aeromekhanika, 2005, vol. 10, no. 2, pp. 243-248. (in Russian)

[9] D.N. Gorelov and V.P. Krivospitskii. "Perspektivy razvitiya vetroenergeticheskikh ustanovok s ortogonal'nym rotorom [Prospects for development of wind power units with orthogonal rotor]". Teplofizika i aeromekhanika, 2008, vol. 15, no. 1, pp. 163-167. (in Russian)
[10] D.N. Gorelov. “Energeticheskie kharakteristiki rotora Dar'e [Energy characteristics of Darrieus rotor (overview)]". Teplofizika i aeromekhanika, 2010, vol. 17, no. 3, pp. 325-333. (in Russian)

[11] I.I. Ivanov, G.A. Ivanova, O.L. Perfilov. "Model'nye issledovaniya rotornykh rabochikh kolyos vetroenergeticheskikh stantsyi [Model studies of rotor impellers of wind power stations]". Sbornik trudov Gidroproekta "Vetroenergeticheskie stantsii", Moscow [Proc. of the Gidroproekt "Wind energy stations", Moscow], 1988, no. 129, pp. 106-113. (in Russian)

[12] V.P. Kharitonov. Avtonomnye vetroelektricheskie ustanovki [Autonomous wind electric power stations]. Moscow, 2006, 280 p. (in Russian)

[13] P.G. Baklushin, V.V. Samsonov, K.P. Vashkevich. "Eksperimental'nye issledovaniya aerodinamicheskikh kharakteristik ortogonal'nykh kryl'chatukh vetrokolyos [Experimental research of aerodynamics characteristics of orthogonal blade wind turbines]" Sbornik trudov Gidroproekta "Vetroenergeticheskie stantsii", Moskva [Proc. of the Gidroproekt "Wind energy stations", Moscow], 1988, no. 129, pp. 98105. (in Russian)

[14] A.M. Fedyushkin and O.V. Levinskikh. "Experimental research of the wind turbine with a vertical axis of rotation" Tematicheskii sbornik nauchnykh trudov KhAl im. Zhukovskogo N.E. "Konstruktsiya i okhlazhdenie elektricheskikh mashin bezodkhodnoi tekhnologii", Kharkov [Thematic proc. Of KhAl named Zhukovsky N.E. "Design and cooling of electric machines of waste-free technology", Kharkov], 1986, pp. 160-166. (in Russian)

[15] A.N. Razdobarin. "Raschyot vozdeistviya nestatsionarnykh poryvov na obtekanie profilya [Calculation of influence of non-stationary impulses on profile flow]". Trudy Tsentral'nogo aerodinamicheskogo instituta imeni N.E. Zhukovskogo [Proc of Central aero-hydrodynamics institute named N.E. Zhukovskii], 1996, no. 2622, pp. 3-14. (in Russian)

[16] V.M. Kovalenko and L.G. Rozhkova. "Vertikal'no-osovi vetroustanovky serednyoi bystrokhodnosti [Vertical-axial wind stations with average rapidity]" Zbirka prats' II Ukrajins'koji naukovo-tekhnichnoji konferentsiji "gidromekhanika $v$ inzhenernii praktytsi" [Proc. Ukrainian Scientific and Technical Conference "Hydromechanical in Engineering Practice"]. Kyiv-Cherkassy, 1997, pp. 202-204. (in Ukrainian)

[17] L.G. Rozhkova. Novi formy profiliv lopatei vertykalno-osovykh vitroustanovok serednyoji shvydkokhidnosti. [New forms of profiles of blades vertical-axial wind stations with average rapidity]. Dissertation. Sumy, 2005, 160 p. (in Ukrainian)

[18] V.M. Kovalenko, et al. Vetrokoleso [Wind turbine]. Patent USSR, no. 176549368, 1992. (in Russian)

[19] L.G. Rozhkova. Lopast' vetrokolesa [Blade of wind turbine]. Patent USSR, no. 1815409, 1993. (in Russian)

[20] L.G. Rozhkova and E.G. Kuznetsov. Vitrokoleso vertykalnoossyovoji vitroustanovky z lopatyamy typu KN [Wind turbine of vertical-axial wind station with blades of KN type]. Patent Ukraine, no. 124107, 2018. (in Ukrainian)

[21] A. Panda, Š. Olejárová, J. Valíček and M. Harničárová. "Monitoring of the condition of turning machine bearing housing through vibrations". International Journal of Advanced Manufacturing Technology, vol. 97, no. 1-4, pp. 401-411, 2018. 
[22] M. Rimar, M. Fedak, A. Kulikov and P. Smeringai. "Study of gaseous flows in closed area with forced ventilation". MM Science Journal, vol. 2018, no. March, pp. 2188-2191, 2018.

[23] A. Panda, V. Nahornyi, I. Pandová, M. Harničárová, M. Kušnerová, J. Valíček and J. Kmec. "Development of the method for predicting the resource of mechanical systems". International Journal of Advanced Manufacturing Technology, vol. 105, no. 1-4, pp. 1563-1571, 2019.

[24] S. Olejarova, J. Dobransky, J. Svetlik and M. Pituk. "Measurements and evaluation of measurements of vibrations in steel milling process". Measurement, vol. 106, pp. 18-25, 2017. ISSN 0263-2241.

[25] J. Valicek, M. Harnicarova, I. Kopal, Z. Palková, M. Kušnerová, A. Panda and V. Šepelák. "Identification of Upper and Lower Level Yield strength in Materials". Materials, vol. 10, no. 9, pp. 1-20, 2017.

[26] A. Panda and J. Duplak. "Comparison of theory and practice in analytical expression of cutting tools durability for potential use at manufacturing of bearings". Applied Mechanics and Materials, vol. 616, pp. 300-307, 2014.

[27] A. Panda, K. Dyadyura, J. Valicek, M. Harnicarova, J. Zajac, V. Modrak, I. Pandova, P. Vrabel, E. Novakova-Marcincinova and Z. Pavelek. "Manufacturing Technology of Composite Materials - Principles of Modification of Polymer Composite Materials Technology Based on Polytetrafluoroethylene". Materials, vol. 10, no. 4, pp. 337, 2017.
[28] A.S. Chaus, et al. "Complex fine-scale diffusion coating formed at low temperature on high-speed steel substrate". Applied Surface Science, vol. 437, pp. 257-270, 2018.

[29] W. Bialy and J. Ružbarský. "Breakdown cause and effect analysis. Case study". Management Systems in Production Engineering, vol. 26, pp. 83-87, 2018.

[30] A. Panda, J. Dobránsky, M. Jančík, I. Pandová and M. Kačalová. "Advantages and effectiveness of the powder metallurgy in manufacturing technologies". Metalurgija, vol. 57, no. 4, pp. 353-356, 2018.

[31] K. Monkova and P. Monka. "Some aspects influencing production of porous structures with complex shapes of cells". Lecture Notes in Mechanical Engineering, pp. 267276, 2017.

[32] L'. Straka, I. Čorný and J. Pitel'. "Prediction of the geometrical accuracy of the machined surface of the tool steel EN X30WCrV9-3 after electrical discharge machining with CuZn37 wire electrode". Metals, vol. 7, no. 11, pp. 1-19, 2017.

[33] L'. Straka, I. Čorný and J. Pitel'. "Properties evaluation of thin microhardened surface layer of tool steel after wire EDM". Metals, vol. 6, no. 5, pp. 1-16, 2016.

\section{Ludmila Rozhkova \\ ORCID ID: 0000-0002-1068-8959 \\ Sumy National Agrarian University \\ Faculty of Food Technologies \\ $160 \mathrm{H}$. Kondratieva st., 40000 Sumy, Ukraine \\ e-mail: rozhkova_lg@ukr.net}

\section{Tibor Krenicky}

ORCID ID: 0000-0002-0242-2704

Technical University of Kosice

Faculty of Manufacturing Technologies

Sturova 31, 08001 Presov, Slovakia

e-mail: tibor.krenicky@tuke.sk

\section{Eduard Kuznetsov}

ORCID ID: 0000-0003-3966-9724

Sumy State University

Faculty of Electronics and Information Technologies

2, Rymskogo-Korsakova st., 40007 Sumy, Ukraine

e-mail:v.nahornyi@cs.sumdu.edu.ua

\section{Volodymyr Nahornyi}

ORCID ID: 0000-0001-5223-7219

Sumy State University

Faculty of Electronics and Information Technologies

2, Rymskogo-Korsakova st., 40007 Sumy, Ukraine 